\title{
Design and Optimisation of a Microgrid for Improved Efficiency of the Volta River Authority (Navrongo) Solar Power Plant
}

\author{
Anthony Simons ${ }^{1}$, , Otoo Henry ${ }^{2}$, Kuubeterzie Francis ${ }^{1}$, Cyrus Addy ${ }^{1}$ \\ ${ }^{1}$ Department of Mechanical Engineering, University of Mines and Technology, Tarkwa, Ghana \\ ${ }^{2}$ Department of Mathematical Sciences, University of Mines and Technology, Tarkwa, Ghana
}

\section{Email address:}

asimons@umat.edu.gh (A. Simons),hotoo@umat.edu.gh (O. Henry)

${ }^{*}$ Corresponding author

\section{To cite this article:}

Anthony Simons, Otoo Henry, Kuubeterzie Francis, Cyrus Addy. Design and Optimisation of a Microgrid for Improved Efficiency of the Volta River Authority (Navrongo) Solar Power Plant. American Journal of Mechanical and Industrial Engineering. Vol. 5, No. 3, 2020 , pp. 44-52. doi: 10.11648/j.ajmie.20200503.12

Received: May 19, 2020; Accepted: June 11, 2020; Published: August 13, 2020

\begin{abstract}
In ensuring proper energy mix and reducing the number of emissions from traditional thermal plants for power generation, the Energy Commission of Ghana built the Solar Power Plant at Navrongo. This was to help cut down the cost of crude fuel imports and also play a part in mitigating global warming which results from the continuous emission of carbon dioxide $\left(\mathrm{CO}_{2}\right)$ at the thermal power. Over the years the plant has been faced with inconsistent power generation. This research paper sought to investigate the power losses at the Navrongo Volta River Authority (VRA) Solar Power Plant and come out with measures to improve its efficiency. Power production downtime and power transmission losses were identified as the major constraints of the solar power plant. General evaluation and review of the grid design and transmission system of the plant were considered and a microgrid technology was proposed to eliminate generation downtime and power transmission losses. The output of the proposed microgrid system was predicted using R-studio statistical simulations, also the plant was optimised to ascertain the gains in power generation and the merits of this system were discussed. Finally, conclusions and recommendations where made to ensure energy security and economic competitiveness of the plant.
\end{abstract}

Keywords: Microgrid, Solar Power Plant, Energy Loss, Energy Output, Invertors

\section{Introduction}

The Energy Commission of Ghana in ensuring proper energy mix and reducing the number of emissions from traditional thermal plants for power generation, built the Solar Power Plant at Navrongo. This was to aide Ghana cut down the cost of crude fuel imports and also play a part in mitigating global warming which results from the continuous emission of carbon dioxide $\left(\mathrm{CO}_{2}\right)$ at the thermal power generating stations in the country [1].

It has come to the notice of the management of the plant that there is inconsistent power generation from the plant, this is because the DC inverters are power sensitive, and they depend on the Navrongo-Pungu grid lines for power supply. Again there are transmission losses as Power is generated at Pungu and transmitted to the Navrongo Substation and back to Pungu community for usage. Furthermore, module cracking and high cell temperatures have been also identified as contributing factors to the losses. Consequently, there is a need to improve the power output of the installed solar plants and eliminate the associated power losses.

The Navrongo VRA Solar Plant has an installed capacity of 2.6 MW. However, the actual output is averaged to be 1.5 MW. Subsequently, the output power deficit stands at 1.1 MW in terms of installed capacity. This loss is significant in terms of power supply to the people of Ghana, and when translated into money is about GHф 9,367.74 (USD 1622.46) loss of income per day. To avert all these, this paper analyses the power generation process, performance indexes and ways of improving power efficiency at the solar plant. 


\section{Resources and Method Used}

\subsection{Materials and Procedures Used}

Prefeasibility study was carried out using the master-writing picture: $18^{\text {th }}$ Edition and the multi-functional power meters to measure the amount of energy generated per solar day, amount of energy loss, the energy delivered by the grid system and average energy consumed at the site. Secondary data of the performance of the plant was also obtained from the site for diagnostic analysis. A review of the design criteria and evaluation of the existing grid design and layout of the Solar Power plant was done (Figure 1).

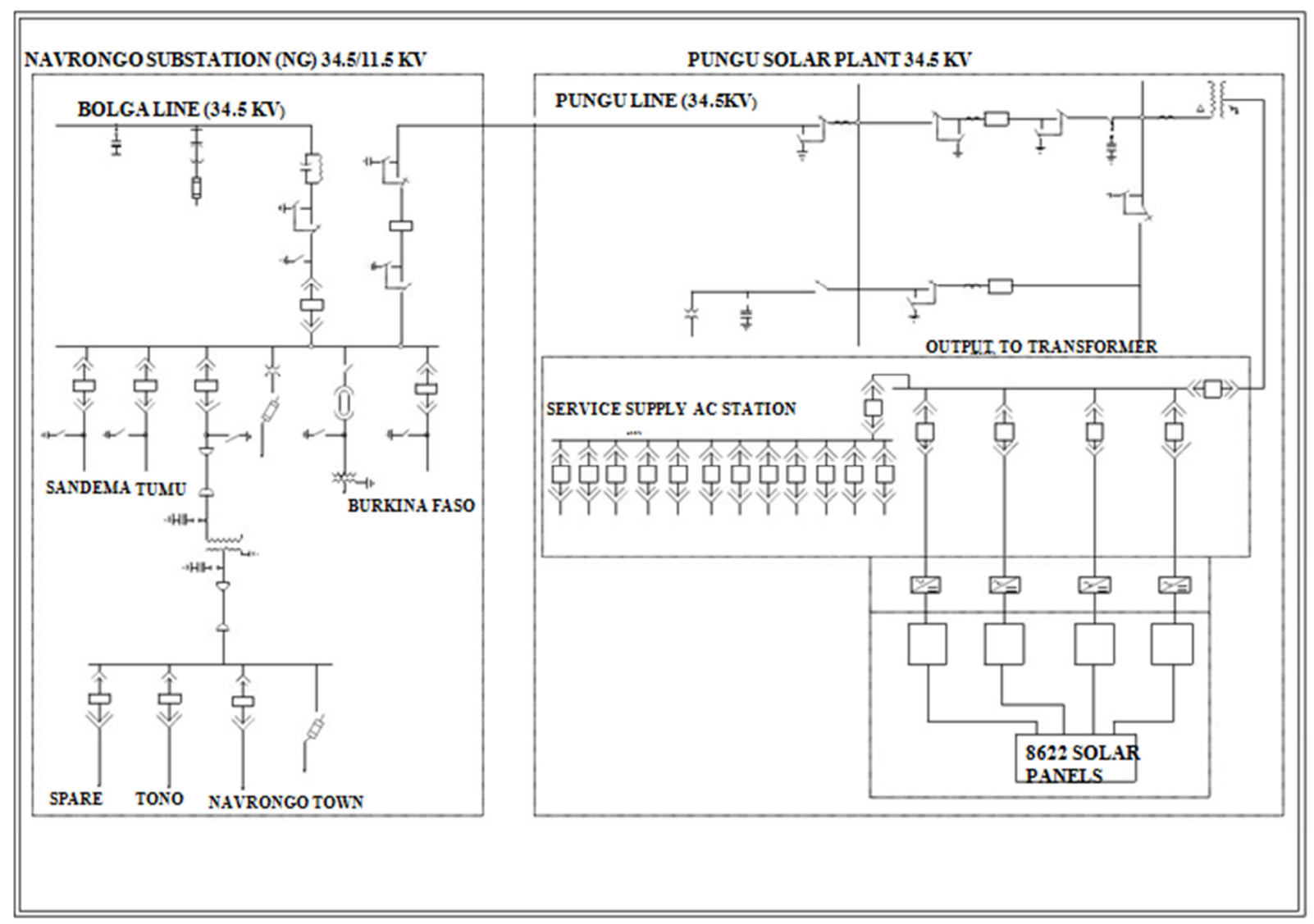

Figure 1. Circuit Diagram of the Existing Navrongo VRA Solar Power Plant.

\subsection{Principles of Operation of Existing Plant}

Figure 1 depicts the circuit diagram of the Navrongo VRA Solar Power Plant which is made up of 120 arrays, 32 combiner boxes and $5 \mathrm{D}$. C inverters. The combiner boxes transfer a composite voltage between 700 to 900 volts of DC to the inverters which transform it into 415 volts of AC. The AC transformer receives the 415 volts from the inverters and steps it up to $34.5 \mathrm{kV}$. Power from the transformer unit is delivered into the Pungu line for transmission into the Navrongo Substation which also receives power from Bolgatanga. The Navrongo Substation supplies energy to the Navrongo town, Burkina Faso, Tumu, Sandema, Tono and Spare for consumption. Again, power is transmitted back to Pungu township for consumption and this to and fro of power transmission between Pungu and Navrongo increases transmission power losses coupled with the grid-power sensitive nature of the D. C inverters which gets the plant shut down whenever the grid is off. It is imperative that a solution be found to improve efficiency of the solar power plant and supply of power to the Pungu Community.

\subsection{Proposed Microgrid Design and Description}

The losses encountered during transmission and the power inconsistencies during grid decoupling or grid-tying conditions has resulted in the need for design of a microgrid system for continuous power supply.

The advantage of a Microgrid is that it operates autonomously within the grid power network system. Power consumers derive a steady and dependable source of energy as against being tied to the grid for power supply [2]. Generating power by the microgrid technology system and small-scale renewable energy resources improves energy efficiency and also has environmental advantages over the large-scale grid generation system [3].

The Microgrid technology further strengthens the efforts of the concept of the smart grid for locally produced power and focuses on power supplies which satisfy the needs of the consumers served [4]

Moreover, the Microgrid system power generation is not affected by downtime, transmission losses and power rationing. Microgrid power generation is unique and allows consumers 
the choice to generate power based on their needs [5].

Consequently, the design of a microgrid was proposed which is depicted in Figure 2. The proposed Microgrid for Pungu community is composed of a group of interconnected loads and power supply resource in a clearly defined electrical network that acts as a single regulated unit with respect to the grid. The Microgrid can be connected and disconnected from the grid relative to the rotation of solar day and night [6].

\subsection{Description of Design}

The circuit diagram in Figure 2 consists of the PV arrays wired into combiner boxes that deliver a DC voltage into the DC inverters. An AC circuit breaker is stationed between the DC inverter and the multi-purpose transformer. There are two lightning arresters connected at the output of the inverters by a circuit breaker and also at the output of the transformer. Two earthing wires are each fixed at the two output paths. The potential transformer maintains the value of the power to be transmitted into the Pungu community for consumption.

A start-up power generator is incorporated to initiate the inverters into action during generation time. The automatic change over switch makes it possible for the pungu community to still draw power from the national grid when the solar plant is not generating energy to maintain continuity of power supply. The power consumption of the Pungu community is measured to be $2.8 \mathrm{MW}$.

However, the plant has an installed capacity of $2.6 \mathrm{MW}$ and generates 1.5 MW which is $1.1 \mathrm{MW}$ less than the power requirements of the community. Therefore, there is the need to:

Segregate consumers with low energy consumption and give them solar panels; and

Design a mircogrid for the community to ensure that whatever amount of power generated is utilised by communities. This will curb energy losses due to transmission and downtime.

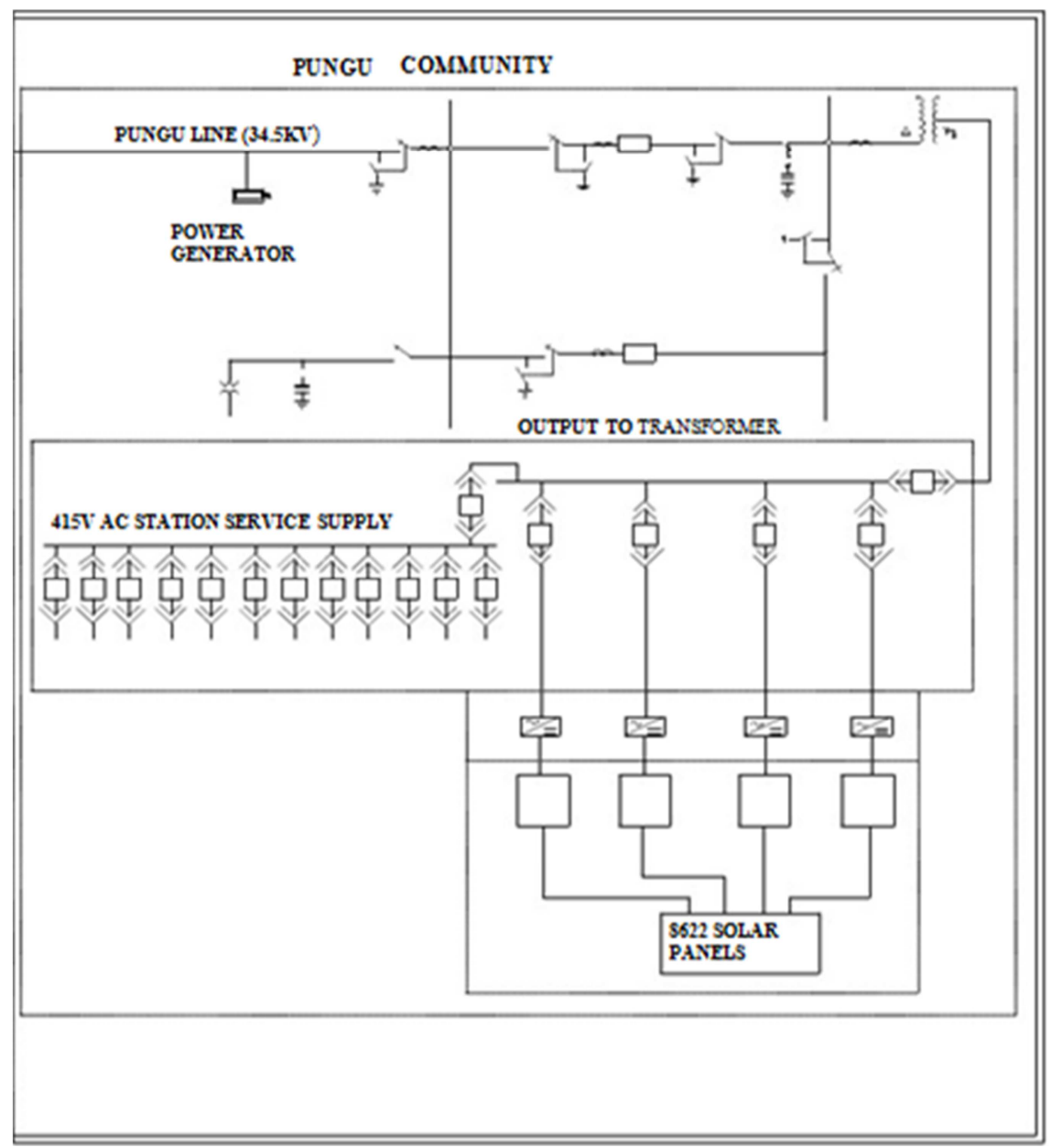

Figure 2. Proposed Microgrid Design for the NavrongonVRA Solar Power Plant.

\section{Performance Analysis of Power Output of the Microgrid}

It was determined from data at the plant that, about $21 \%$ of the energy loss is attributable to production downtime, and also $26 \%$ by transmission losses as similar findings by Asmus and Stimmel [7].

In the old system, when generation downtime occurs the PV arrays continue to generate between $700 \mathrm{~V}$ to $900 \mathrm{~V}$ of DC power, which goes waste at the solar cells because the inverters stop procession for lack of power in the grid 
transmission lines whilst, the microgrid does not depend on power in the grid. The R-studio statistical software was used to analyse the proposed system and the results yielded.

In deed to predict the effectiveness of the microgrid, simulations were done using R-studio and about $47 \%$ loss via transmission and downtime in the current setup was eliminated. This step was essential because for a standalone PV system the losses due to transmission and downtime are void since the energy generated would be the exact energy consumed. The grid connected power output readings were recorded alongside the simulated output of the microgrid, to help evaluate the gains of the microgrid system over the existing solar power plant.

The percentage of power gained by the microgrid technology is determined as:

$$
\text { Percentage Gain in Power }=\frac{\text { Microgrid Output-Grid Output }}{\text { Grid Output }} \times 100 \%
$$

The theory of solar cells explains the process by which light energy in photons is converted into electric current when photons strike a suitable semiconductor device [8].

The theory foretells the functional limits of PV cell, and offer guidance on the constraints that lead to losses and also indicates the solar cell efficiency [9]. Mismatch losses arise if the PV modules in use have different physical and chemical compositions. But are wired together in series and in parallel. [10].

It should be stated that, the electrical output from a single cell is small, so multiple cells are connected and encapsulated to form a module [11]. Therefore, the selection of modules is important in the overall performance of the plant and it involves the knowledge of the solar cell theory [12]. Usually, the more sunlight hitting the modules, the more current they will produce [13].

The temperature of PV cells is one of the most important variables used in assessing the performance of PV systems and their electrical energy production [14]. This temperature depends on parameters such as the thermal properties of materials used in PV module encapsulation, type of PV cells, configuration of PV modules' installation and local climatic conditions which are governed by the theory of solar cells [15].

\section{PV Optimisation Model Equation, Resuts and Dicussuion}

Microgrid has been designed for the plant, however, for improved efficiency of the system, there is the need to look at some parameters that influence the magnitude of power generation and how to optimise it.

Consequently, a mathematical model was developed to determine the optimum power that can be generated taking cognizance of the following constraints; general efficiency, cell efficiency, dust deposition, cell and ambient temperatures, peak sun hours, irradiance and total PV module area.

The objective function of the mathematical optimisation can be expressed as:

Constraints

$$
\begin{gathered}
\mathrm{C}_{1}: 31 \leq \mathrm{X}_{1} \leq 36 \mathrm{OR}_{1} \leq \mathrm{X}_{1} \leq \mathrm{a}_{2} \\
\mathrm{C}_{2}: \mathrm{X}_{2} \leq 67 \mathrm{OR} \mathrm{X}_{2} \leq \mathrm{b} \\
\mathrm{C}_{3}: 0.84 \leq \mathrm{X}_{3} \leq 0.992 \text { OR D }_{1} \leq \mathrm{X}_{3} \leq \mathrm{D}_{2} \\
\mathrm{C}_{4}: \mathrm{X}_{2}=\mathrm{X}_{1}+((\text { NOCT }-20) / 0.8) \times \mathrm{X}_{3} \leq \mathrm{b}
\end{gathered}
$$

Where,

$\mathrm{a}_{1}=$ minimum ambient temperature $\left({ }^{\circ} \mathrm{C}\right)$

$\mathrm{a}_{2}=$ maximum ambient temperature $\left({ }^{\circ} \mathrm{C}\right)$

$\mathrm{b}=$ maximum cell temperature $\left({ }^{\circ} \mathrm{C}\right)$

$\mathrm{D}_{1}=$ minimum irradiance $\left(\mathrm{kWh} / \mathrm{m}^{2}\right)$

$\mathrm{D}_{2}=$ maximum irradiance $\left(\mathrm{kWh} / \mathrm{m}^{2}\right)$

$\mathrm{X}_{1}=$ ambient temperature $\left({ }^{\circ} \mathrm{C}\right)$

$\mathrm{X}_{2}=$ cell temperature $\left({ }^{\circ} \mathrm{C}\right)$

$\mathrm{X}_{3}=$ irradiance $\left(\mathrm{kWh} / \mathrm{m}^{2}\right)$

$\mathrm{NOCT}=$ normal operating cell temperature

Alternatively,

$$
\text { Optimum Power }(P)=\left(1-\left(d \times\left(X_{2}-e\right) \times f \times g \times X_{3} \times h \times I\right)\right.
$$

where,

$\mathrm{d}=$ temperature coefficient $\left(0.00845 /{ }^{\circ} \mathrm{C}\right)$

$\mathrm{e}=$ temperature at $\operatorname{STC}\left(25^{\circ} \mathrm{C}\right)$

$\mathrm{f}=\operatorname{dirt}$ rating $(0.93)$

$\mathrm{g}=$ cell efficiency $(0.15)$

$\mathrm{h}=$ peak sun hours by the average number of days per month $(5 \times 30)$

I = total surface area of PV modules Using equation 1, with the various constraints stated, miscrosoft excel was used to compute the optimized values. The optimized values are indicated in Tables 1, 2, 3 and 4; and Figures 3, 4, 5 and 6 respectively for the years 2013, 2014, 2015, 2016 data records.

From Figure 3, the month of June had the lowest optimised energy generated because it recorded the lowest rang of irradiance of $872 \mathrm{Wh} / \mathrm{m}^{3}$ to $78 \mathrm{Wh} / \mathrm{m}^{3}$ as indicated in Table 1 . The highest optimised energy occurred at $48.6^{\circ} \mathrm{C}$ cell temperature.

$$
\text { Optimum power }(P)=\left(1-\left[(0.00845) \times\left(X_{2}-25\right) \times(0.93) \times(0.15) \times X_{3} \times 150 \times(16729.71)\right]\right)
$$


Table 1. Optimised Average Monthly Power Characteristics for 2013.

\begin{tabular}{|c|c|c|c|c|c|c|c|}
\hline Month & $\begin{array}{l}\text { Energy Gen. } \\
(\mathrm{kWh})\end{array}$ & $\begin{array}{l}\text { Optimised } \\
\text { Energy (kWh) }\end{array}$ & $\begin{array}{l}\text { Maximum } \\
\text { Irradiance } \\
\left(\mathbf{W h} / \mathbf{m}^{2}\right)\end{array}$ & $\begin{array}{l}\text { Minimum } \\
\text { Irradiance } \\
\left(\mathbf{W h} / \mathbf{m}^{2}\right)\end{array}$ & $\begin{array}{l}\text { Maximum } \\
\text { Envir. Temp. } \\
\left({ }^{\circ} \mathrm{C}\right)\end{array}$ & $\begin{array}{l}\text { Minimum } \\
\text { Envir. Temp. } \\
\left({ }^{\circ} \mathrm{Cs}\right)\end{array}$ & Cell Temp. $\left({ }^{\circ} \mathrm{C}\right)$ \\
\hline January & 242555.8 & 340350.9 & 1002 & 932 & 36.2 & 35.0 & 50.7 \\
\hline February & 240770.0 & 445690.0 & 1072 & 930 & 36.0 & 34.5 & 48.6 \\
\hline March & 299741.8 & 417874.3 & 1002 & 879 & 36.0 & 34.0 & 54.4 \\
\hline April & 278799.0 & 386742.8 & 1107 & 723 & 37.0 & 35.0 & 60.0 \\
\hline May & 292741.4 & 389473.7 & 1086 & 779 & 36.9 & 30.9 & 58.4 \\
\hline June & 254220.0 & 105788.0 & 872 & 78 & 32.0 & 22.8 & 54.8 \\
\hline July & 203324.7 & 292993.6 & 1004 & 144 & 34.0 & 27.5 & 52.7 \\
\hline August & 116057.2 & 186552.6 & 873 & 332 & 29.5 & 21.8 & 42.6 \\
\hline September & 269507.7 & 375693.2 & 979 & 375 & 33.0 & 21.0 & 52.4 \\
\hline October & 327921.7 & 339998.0 & 1150 & 384 & 34.0 & 30.9 & 55.3 \\
\hline November & 321748.2 & 436281.8 & 946 & 890 & 36.0 & 33.8 & 56.4 \\
\hline December & 270171.2 & 373489.4 & 1056 & 640 & 35.2 & 28.6 & 55.8 \\
\hline Total & 3117558.7 & 4090928.3 & & & & & \\
\hline
\end{tabular}

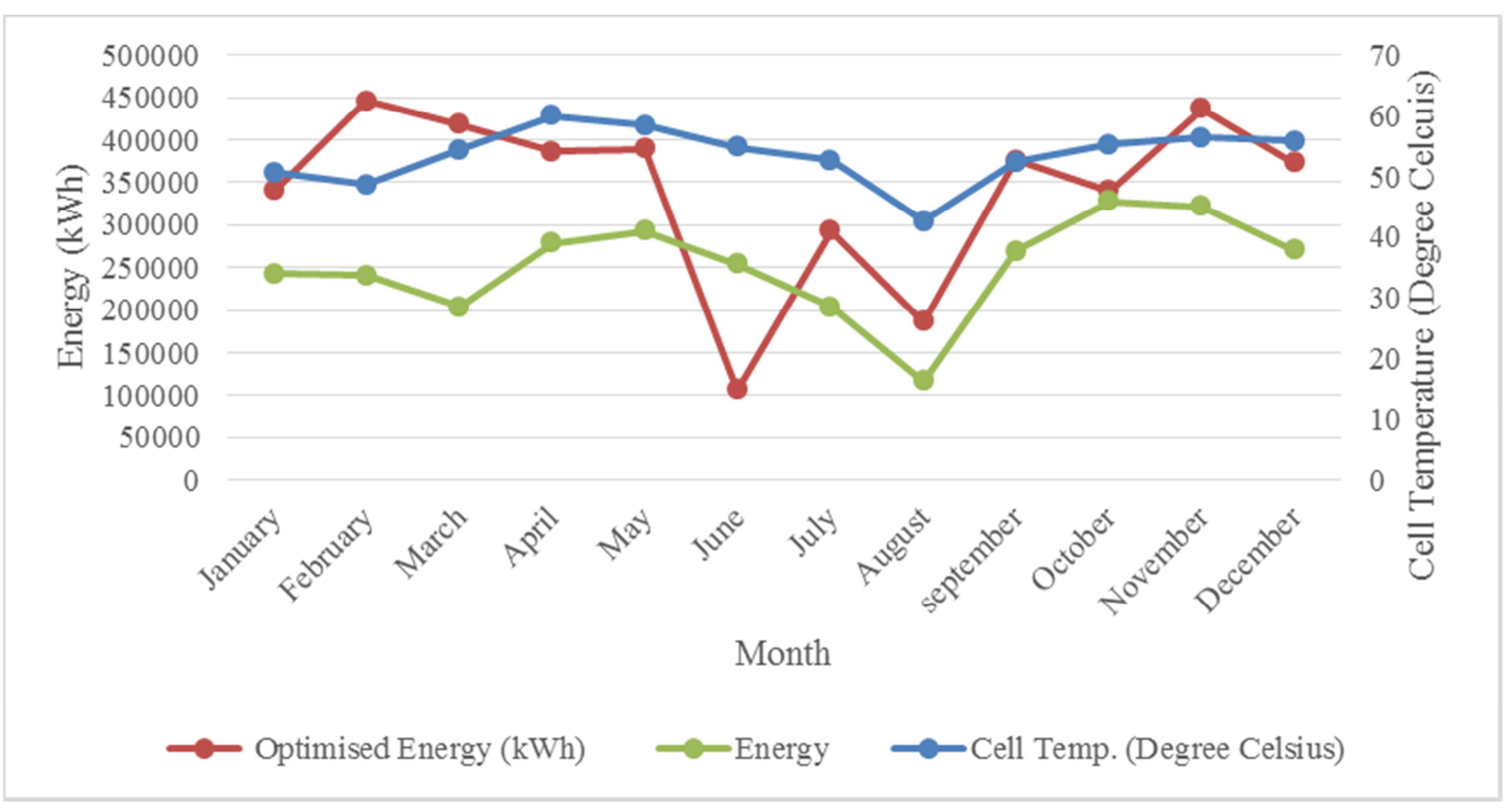

Figure 3. Graphs of Nominal Power Generated and Optimised Power over Months of the Year 2013 at Cell Temperatures.

Table 2. Optimised Average Monthly Power Characteristics for 2014.

\begin{tabular}{|c|c|c|c|c|c|c|c|}
\hline Month & $\begin{array}{l}\text { Energy Gen. } \\
(\mathrm{kWh})\end{array}$ & $\begin{array}{l}\text { Optimised } \\
\text { Energy (kWh) }\end{array}$ & $\begin{array}{l}\text { Maximum } \\
\text { Irradiance } \\
\left(\mathbf{W h} / \mathbf{m}^{2}\right)\end{array}$ & $\begin{array}{l}\text { Minimum } \\
\text { Irradiance } \\
\left(\mathbf{W h} / \mathbf{m}^{2}\right)\end{array}$ & $\begin{array}{l}\text { Maximum } \\
\text { Envir. Temp. } \\
\left({ }^{\circ} \mathrm{C}\right) \\
\end{array}$ & $\begin{array}{l}\text { Minimum } \\
\text { Envir. Temp. } \\
\left({ }^{\circ} \mathrm{Cs}\right)\end{array}$ & $\begin{array}{l}\text { Cell } \\
\text { Temp. } \\
\left({ }^{\circ} \mathrm{C}\right)\end{array}$ \\
\hline January & 293001.4 & 351601.7 & 1006 & 910 & 37.0 & 35.0 & 50.7 \\
\hline February & 214454.5 & 257345.4 & 1078 & 983 & 36.5 & 34.5 & 48.6 \\
\hline March & 395064.3 & 474077.2 & 1002 & 925 & 36.0 & 34.0 & 54.4 \\
\hline April & 360307.8 & 432369.4 & 1139 & 952 & 35.6 & 35.0 & 60.0 \\
\hline May & 347509.1 & 417010.9 & 1097 & 723 & 36.9 & 30.9 & 58.4 \\
\hline June & 354440.7 & 487328.8 & 1175 & 943 & 35.8 & 22.8 & 54.8 \\
\hline July & 343339.6 & 512890.5 & 1127 & 571 & 35.0 & 27.5 & 52.7 \\
\hline August & 277333.1 & 332799.7 & 834 & 519 & 33.2 & 21.8 & 42.6 \\
\hline September & 328237.5 & 393885.0 & 1224 & 975 & 33.2 & 21.0 & 52.4 \\
\hline October & 382538.8 & 459046.6 & 1101 & 930 & 35.7 & 30.9 & 55.3 \\
\hline November & 319835.7 & 383802.8 & 992 & 925 & 35.9 & 33.8 & 56.4 \\
\hline December & 347176.5 & 476612.1 & 962 & 905 & 33.8 & 28.6 & 55.8 \\
\hline Total & 3963239 & 4978770 & & & & & \\
\hline
\end{tabular}




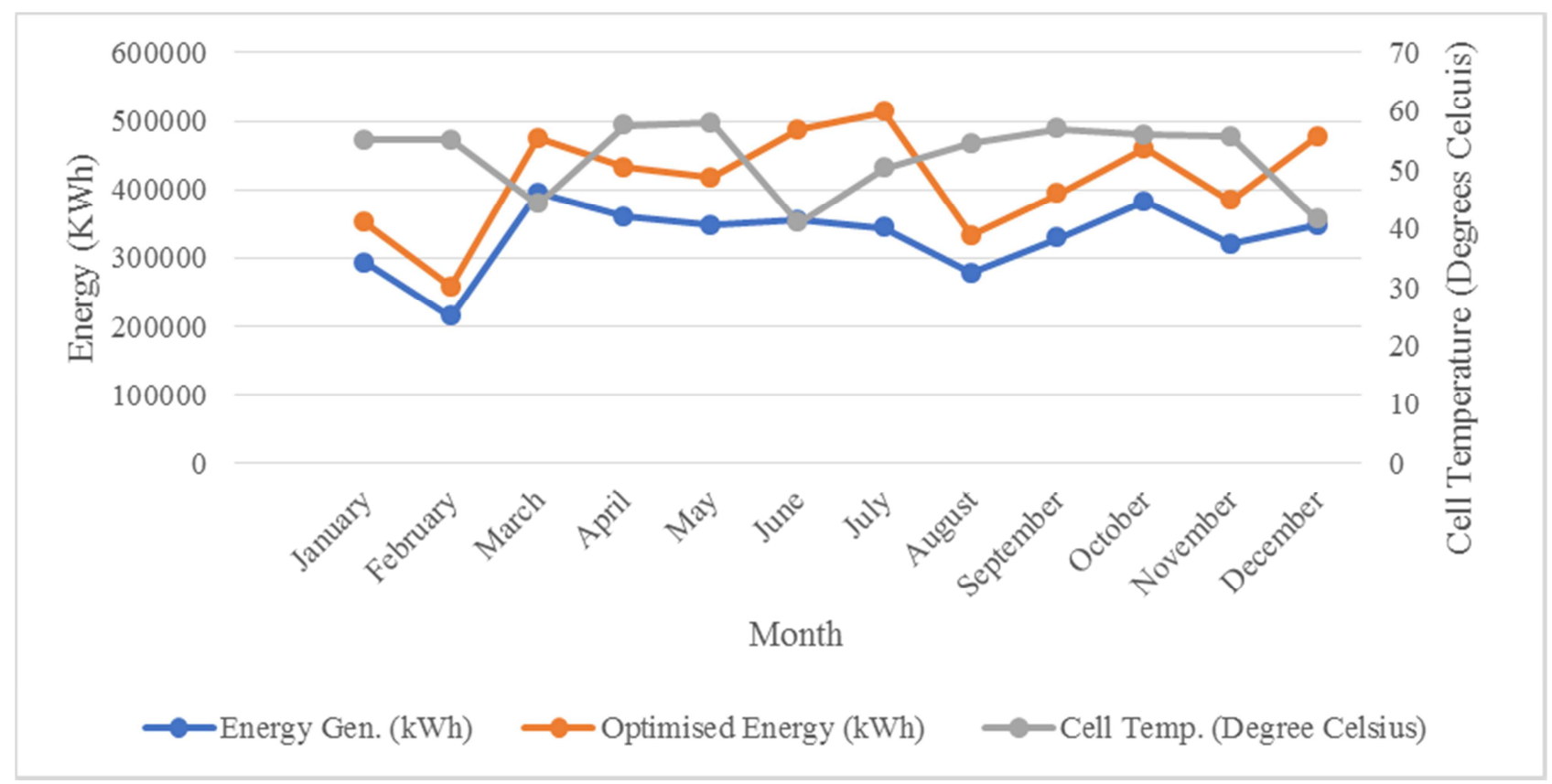

Figure 4. Graph of Nominal Power Generated and Optimised Power over Months of the Year 2014 at Cell Temperatures.

From Figure 4 , at a cell temperature of $50.3^{\circ} \mathrm{C}$ and a minimum ambient temperature of $32.0^{\circ} \mathrm{C}$, an optimised energy of $512,890.5 \mathrm{kWh}$ was estimated which occurred in July. Thus, maximum power is produced in July at cell temperature of $52.7^{\circ} \mathrm{C}$ with a peak irradiance of $1127 \mathrm{Wh} / \mathrm{m}^{2}$. Also, February had a lower energy generated and optimized energy readings than January even though the constraint values were almost the same. This was due to the fact that there was dust accumulation form November 2013 to February 2014 due to the Harmattan climate condition and cleaning was done only in March 2014.

It is observed that in Figure 5, the highest power was obtained in January 2015 with a cell temperature of $53^{\circ} \mathrm{C}$ and a maximum irradiance of $956 \mathrm{Wh} / \mathrm{m}^{2}$.

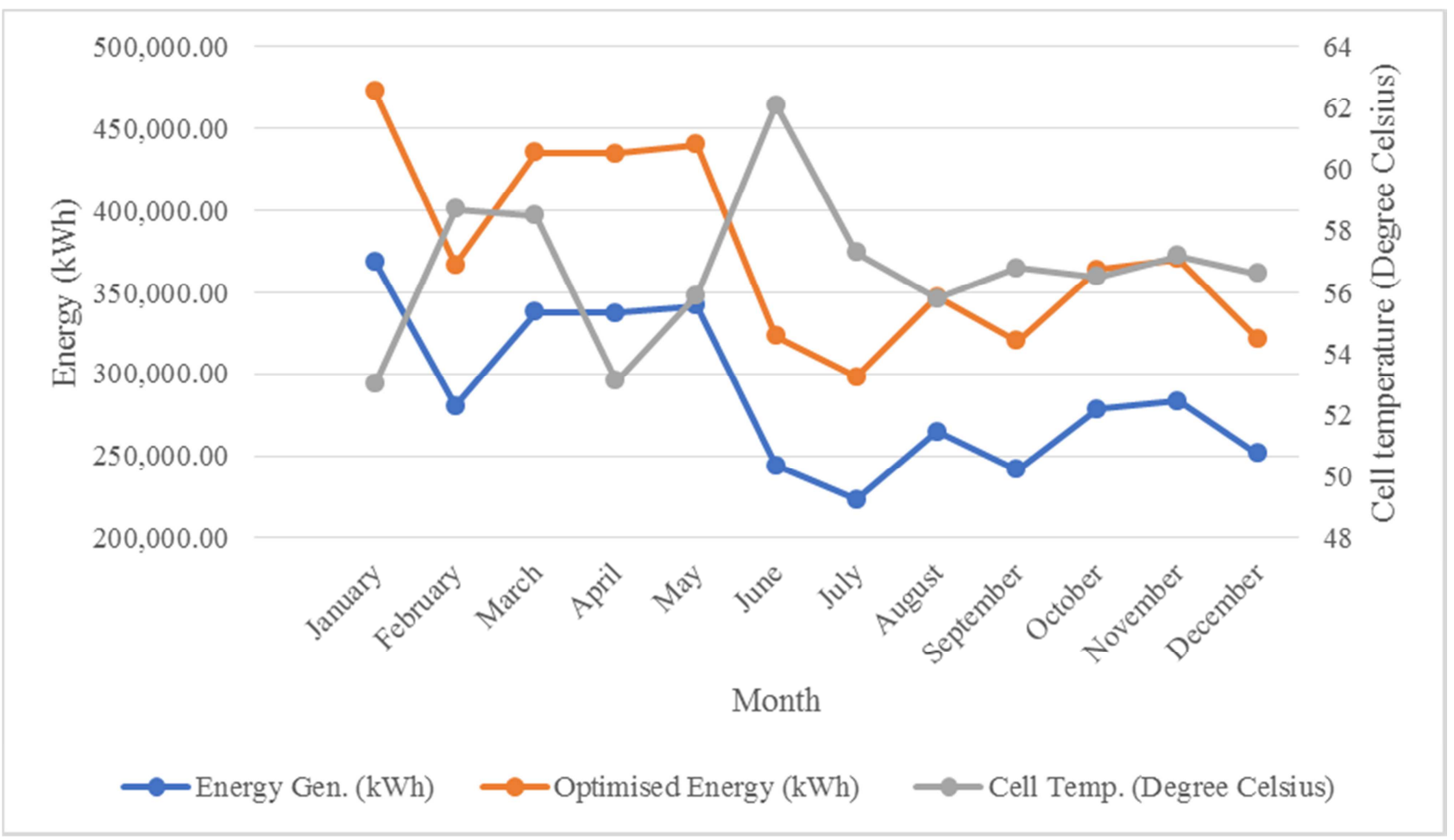

Figure 5. Graph of Nominal Power Generated and Optimised Power over Months of the Year 2015 at Cell Temperatures. 
Table 3. Optimised Average Monthly Power Characteristics for 2015.

\begin{tabular}{|c|c|c|c|c|c|c|c|}
\hline Month & $\begin{array}{l}\text { Energy Gen. } \\
(\mathrm{kWh})\end{array}$ & $\begin{array}{l}\text { Optimised } \\
\text { Energy (kWh) }\end{array}$ & $\begin{array}{l}\text { Maximum } \\
\text { Irradiance } \\
\left(\mathbf{W h} / \mathbf{m}^{2}\right)\end{array}$ & $\begin{array}{l}\text { Minimum } \\
\text { Irradiance } \\
\left(\mathbf{W h} / \mathbf{m}^{2}\right) \\
\end{array}$ & $\begin{array}{l}\text { Maximum } \\
\text { Envir. Temp. } \\
\left({ }^{\circ} \mathbf{C}\right) \\
\end{array}$ & $\begin{array}{l}\text { Minimum } \\
\text { Envir. Temp. } \\
\left({ }^{\circ} \mathrm{Cs}\right) \\
\end{array}$ & $\begin{array}{l}\text { Cell } \\
\text { Temp. } \\
\left({ }^{\circ} \mathrm{C}\right) \\
\end{array}$ \\
\hline January & 368764.8 & 472517.8 & 956 & 898 & 35.1 & 33.1 & 53.0 \\
\hline February & 280540.1 & 366648.1 & 889 & 504 & 36.0 & 34.6 & 58.7 \\
\hline March & 337681.4 & 435217.7 & 1124 & 811 & 36.2 & 34.5 & 58.5 \\
\hline April & 337408.8 & 434890.6 & 1055 & 986 & 36.4 & 35.2 & 53.1 \\
\hline May & 341967.2 & 440360.6 & 1079 & 469 & 37.4 & 35.0 & 55.9 \\
\hline June & 244077.0 & 322892.2 & 1069 & 640 & 33.5 & 32.0 & 62.1 \\
\hline July & 223190.7 & 297828.8 & 1025 & 699 & 35.0 & 33.1 & 57.3 \\
\hline August & 264371.1 & 347245.3 & 992 & 742 & 35.0 & 34.1 & 55.8 \\
\hline September & 241623.9 & 319948.7 & 1015 & 897 & 36.1 & 34.5 & 56.8 \\
\hline October & 278378.8 & 364054.6 & 1047 & 992 & 36.8 & 35.5 & 56.5 \\
\hline November & 283399.8 & 370079.8 & 1056 & 864 & 35.4 & 34.6 & 57.2 \\
\hline December & 251515.7 & 321818.8 & 1048 & 984 & 35.1 & 33.3 & 56.6 \\
\hline Total & 3452919.3 & 4493503 & & & & & \\
\hline
\end{tabular}

Table 4. Optimised Average Monthly Power Characteristics for 2016.

\begin{tabular}{|c|c|c|c|c|c|c|c|}
\hline Month & $\begin{array}{l}\text { Energy Gen. } \\
(\mathbf{k W h})\end{array}$ & $\begin{array}{l}\text { Optimised } \\
\text { Energy }(k W h)\end{array}$ & $\begin{array}{l}\text { Maximum } \\
\text { Irradiance } \\
\left(\mathrm{Wh} / \mathbf{m}^{2}\right)\end{array}$ & $\begin{array}{l}\text { Minimum } \\
\text { Irradiance } \\
\left(\mathbf{W h} / \mathbf{m}^{2}\right)\end{array}$ & $\begin{array}{l}\text { Maximum } \\
\text { Envir. Temp. } \\
\left({ }^{\circ} \mathrm{C}\right)\end{array}$ & $\begin{array}{l}\text { Minimum } \\
\text { Envir. Temp. } \\
\left({ }^{\circ} \mathrm{Cs}\right)\end{array}$ & $\begin{array}{l}\text { Cell } \\
\text { Temp. } \\
\left({ }^{\circ} \mathrm{C}\right) \\
\end{array}$ \\
\hline January & 240154.2 & 307685.0 & 1006 & 368 & 35.5 & 33.6 & 50.7 \\
\hline February & 246899.9 & 325279.9 & 1041 & 631 & 36.7 & 35.6 & 57.5 \\
\hline March & 296774.2 & 385729.0 & 1016 & 642 & 37.5 & 36.1 & 58.4 \\
\hline April & 276038.7 & 360646.4 & 1130 & 455 & 37.0 & 35.1 & 60.2 \\
\hline May & 289842.8 & 376811.4 & 1090 & 658 & 35.6 & 33.1 & 59.2 \\
\hline June & 264977.1 & 346972.5 & 1056 & 916 & 34.0 & 30.9 & 58.3 \\
\hline July & 174866.0 & 238839.0 & 1028 & 921 & 31.8 & 29.6 & 58.7 \\
\hline August & 274559.6 & 358471.5 & 1092 & 662 & 31.6 & 29.4 & 56.7 \\
\hline September & 324954.9 & 418945.9 & 1038 & 894 & 32.5 & 30.4 & 55.4 \\
\hline October & 387134.0 & 594561.0 & 1024 & 846 & 34.8 & 32.7 & 48.9 \\
\hline November & 316637.4 & 409964.9 & 1033 & 936 & 37.2 & 35.0 & 51.2 \\
\hline December & 368049.7 & 470659.6 & 1065 & 923 & 34.6 & 32.6 & 49.9 \\
\hline Total & 3460889 & 4594566 & & & & & \\
\hline
\end{tabular}

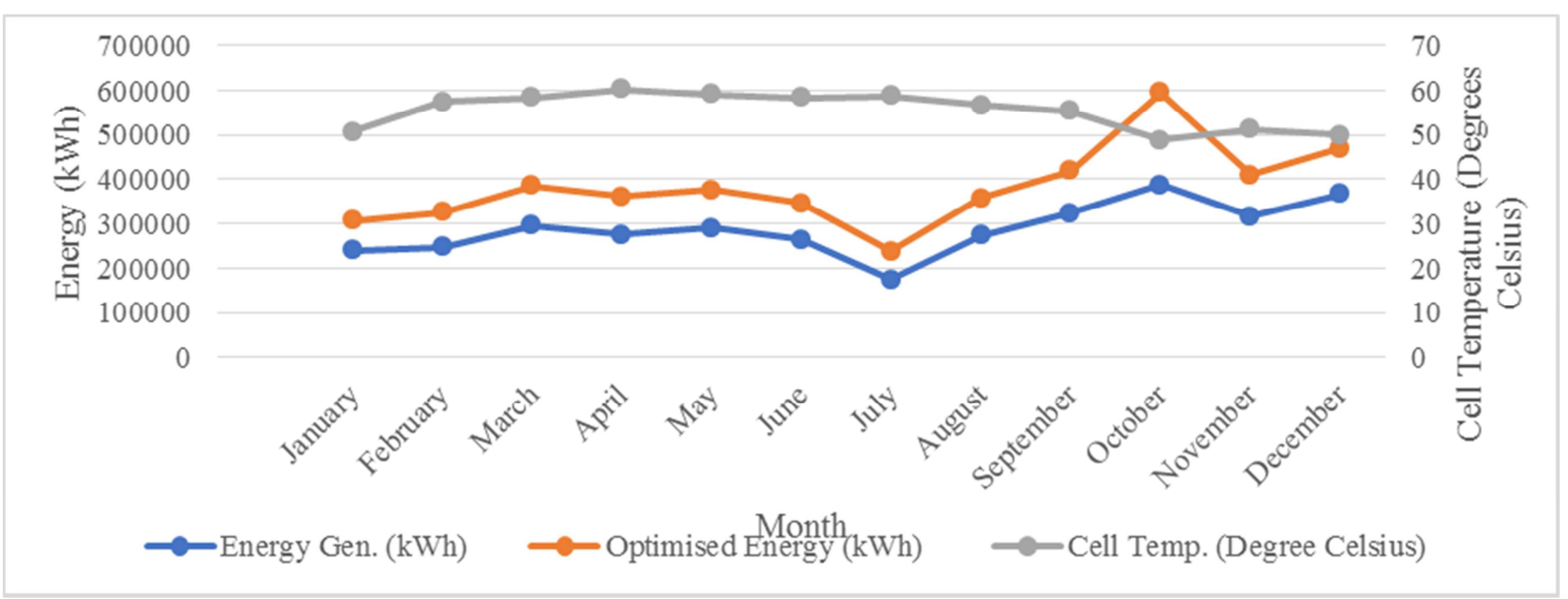

Figure 6. Graph of Nominal Power Generated and Optimised Power over Months of the Year 2016 at Cell Temperatures.

Again, in Figure 6 optimised energy of $594561.0 \mathrm{kWh}$ in October which is the highest, with cell temperature of $48.9^{\circ} \mathrm{C}$ and ambient temperature of $32.7^{\circ} \mathrm{C}$. Furthermore, from Tables 1 to 4, the optimised Power values for each month exceeds the nominal Power generated which depicts a shortfall in the existing power generation system.

To determine the threshold of cell temperatures that resulted in the maximum optimised energy, the optimised energy, and the cell temperatures were stimulated as indicated in Figures 7 and 8 . 

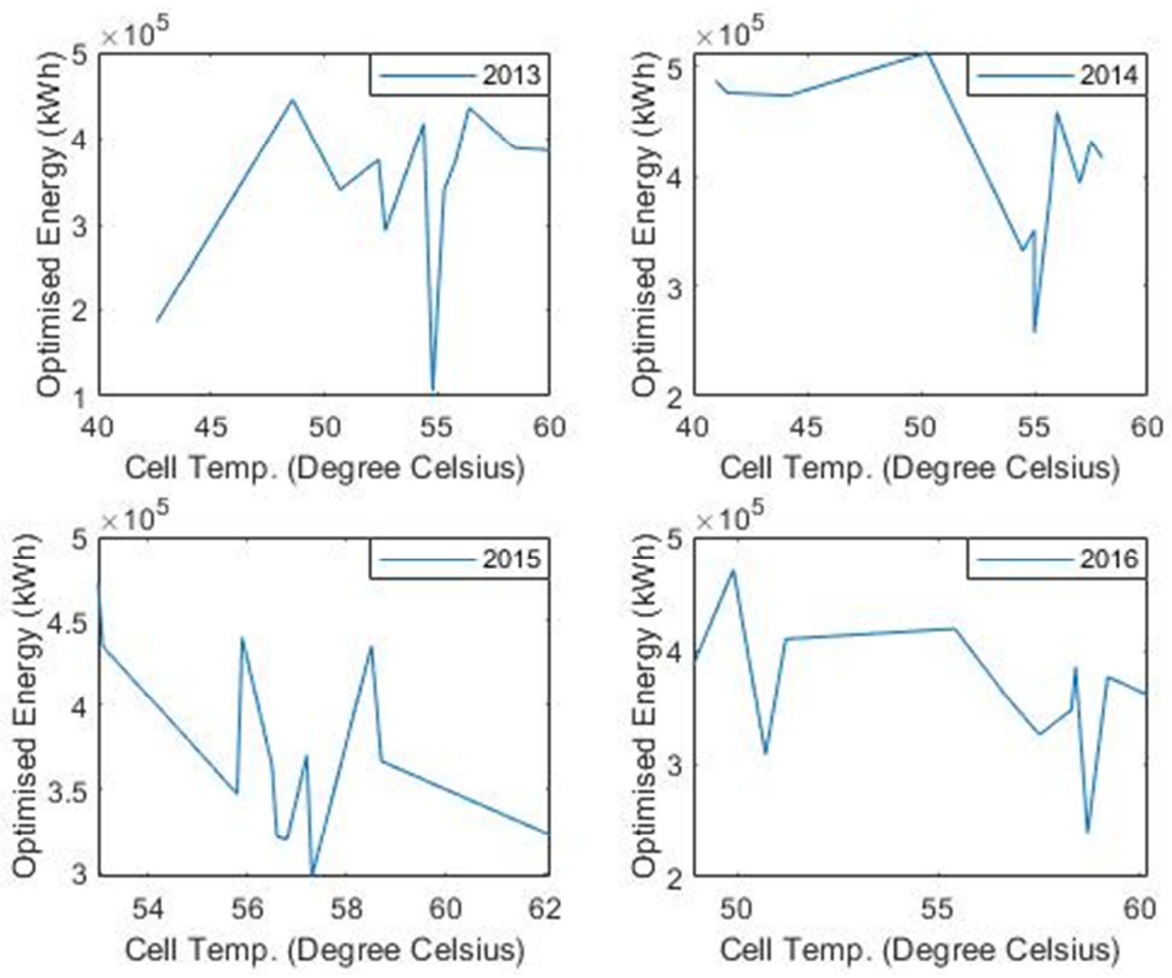

Figure 7. Graph of cell temperature against the Optimised Energy.

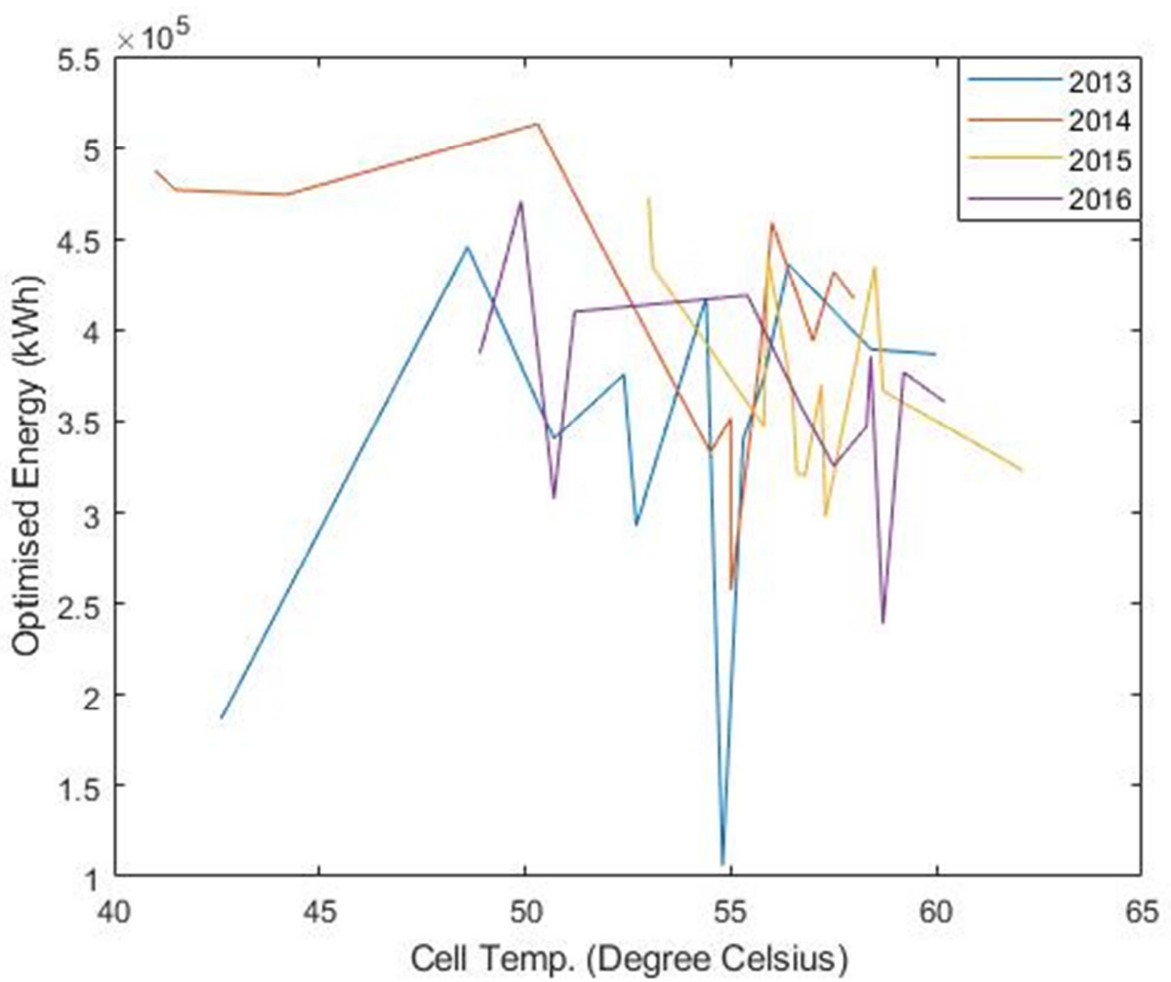

Figure 8. Graph of Cell temperature against the Optimised Energy of the various years.

It could be observed from figure 8 that for the maximum optimized energy to be achieved, the cell temperatures should range from $48.1^{\circ} \mathrm{C}$ to $53^{\circ} \mathrm{C}$.

The plant produces maximum power at peak sun hours with an average cell temperature of $50.8^{\circ} \mathrm{C}$, approximated to
$51{ }^{\circ} \mathrm{C}$.

The study could, therefore, conclude that there is a combination of threshold cell temperature and ambient temperature for which maximum power is delivered. As the cell temperature decreases from $53^{\circ} \mathrm{C}$, the power generated 
increases until a minimum temperature of $48^{\circ} \mathrm{C}$ is reached within which power generation starts decreasing.

Percentage increase after optimisation could be expressed as:

$$
\% \text { increase }=\frac{\text { Optimal value difference }}{\text { Nominal value }} \times 100
$$

The optimised power value difference (O. V. D) is also given as:

$$
\text { O. V. D = Optimised value }- \text { Nominal value }
$$

Table 5 shows the computed optimised values.

Table 5. Optimised value difference and \% increment.

\begin{tabular}{lll}
\hline Year & Optimised Value Difference & \% Increase \\
\hline 2013 & 972739.60 & 31.20 \\
2014 & 2180449.00 & 30.80 \\
2015 & 1040583.70 & 30.10 \\
2016 & 946993.30 & 30.40 \\
\hline
\end{tabular}

\section{Verification of Percentage Increase of Power Generation}

The strength of the PV optimisation module equation was tested further using Rstudio as an alternative method of simulation besides Microsoft excel. The system produced an average boost of $29.8 \%$ of the power output of the solar plant at peak sun hours as compared to $30.4 \%$ boost by the Microsoft excel simulation of the module.

There is therefore convergence in terms percentage power gained, using the two statistical tools in the module simulation.

\section{Conclusions and Recommendations}

\subsection{Conclusions}

Results of the Performance Analysis of the Navrongo VRA solar Plant shows that the major factors associated with power losses at the plant are generation downtime, transmission inefficiencies, module cracking and high cell temperatures.

A new microgrid service system has been designed which will eliminate downtime and power transmission losses.

It was determined from Microsoft Excel and Rstudio that maintaining an optimum cell temperature of $51.0^{\circ} \mathrm{C}$ will boost power output by an average of $30.1 \%$ at peak sun hours and also prevent PV module cracking. From the optimisation, power output will increase on average by $1,285,191.4 \mathrm{kWh}$ per year which translates to $\mathrm{GH} \varnothing$ 965,178.74 (USD 165,789.69) per annum.

\subsection{Recommendations}

The following are the recommendations from the study: Micro-grid design technology should be used in place of the grid transmission system in future investments in solar energy in order to prevent transmission losses and production downtime;
Automatic mist blower systems should be integrated into the solar power plant to maintain the threshold cell temperature of $51^{\circ} \mathrm{C}$ for optimum cell delivery;

Solar trackers are recommended for receiving maximum radiation at any point in time for optimum power delivery of the plant; and further studies should be carried out on the rate of dust deposition on the PV modules.

\section{References}

[1] L. Abdallah and T. EL-Shennaw. Reducing Carbon Dioxide Emissions from Electricity Sector Smart Electric grid Application, J. of Engineering, 2013; 1-8.

[2] R. Gross, M. Leach and A. Bauen, Progress in renewable energy," Environment International, 2003; 29 (1), 105-122.

[3] A. S. Bahaj and P. A. B, James (2007). "Future energy solutions". University of Southampton. Available online: http://www3.hants.gov.uk/fes.pdf (accessed on 4 February 2016).

[4] A. H. Bagdadee and L. Zhang. A Review of Smart Grid Concept for Electrical Power System. Int. J. of Energy and Opt and Eng. 2019: 8 (4), 106-126.

[5] A. S. Bahaj and P. A. B. James. Urban energy generation: the added value of photovoltaics in social housing. Renewable and Sustainable Energy Reviews, 2007; 11 (9), 2121-2136.

[6] S. Bossart (2012), Doe perspective on microgrids: In Advanced microgrid concepts and technologies workshop.

[7] P. Asmus, and C. Stimmel, Utility Distribution Microgrids. Research Report. IGI Global, 2017. Hershy, USA.

[8] Carlson D, Wronski C. Topics in Applied Physics: Amorphous Semiconductors: Amorphous silicon solar cells. 1985. Springer Berlin.

[9] M. A. Green, S. P. Bremner. Energy conversion approaches and materials for high-efficiency photovoltaics. Nature materials. 2017; 16 (1): 23-34.

[10] A. Chouder and S. Silvestre, Analysis model of mismatch power losses in PV systems. Journal of Solar Energy Engineering, 2009, 131 (2) pp. 125-135.

[11] J. Nelson, The physics of solar cells. (2003), Imperial College Press, pp 384.

[12] A. Verma and S. Singhal, Solar PV performance parameter and recommendation for optimization of performance in large scale grid connected solar PV plant-case study. Journal of Energy Power Sources. 2015, (1): 40-53.

[13] J. D. Mondol, Y. G. Yohanis and B. Norton, Optimal sizing of array and inverter for grid-connected photovoltaic systems. 2006, Solar Energy, 80 (12), pp. 1517-1539.

[14] G. Petrone, G. Spagnuolo, R. Teodorescu, M. Veerachary, M. Vitelli. Reliability issues in photovoltaic power processing systems. IEEE transactions on Industrial Electronics. 2008 Jun 24; 55 (7): 2569-80.

[15] M. Green, Third-generation photovoltaics: Advanced solar energy conversion. 2006, Springer, Berlin, pp 163. 